\title{
Introduction
}

In the background of this essay lies a lively discussion about theological or religious reading of the Christian Bible. One way of thinking about theological reading is that what defines it is allowing specifically Christian doctrines and practices to enter into the scope of exegetical arguments. ${ }^{1}$ Such beliefs and practices belong within interpretive deliberations and need not be bracketed out or suspended for the sake of reading the Bible with pristine objectivity, or something approximating that. Another way of thinking about theological reading is to see it not as fundamentally about whether an interpreter can make recourse to doctrine or practice in the act of reading, but about the nature of the text being read as well as of readers themselves. ${ }^{2}$ Thinking of both the interpreted object and the interpreting subject in specifically Christian terms begins from a different starting point, which might be referred to as a theological ontology. These are merely two examples of ways to begin unpacking theological reading, and the purpose of briefly summarizing these agenda statements here is only to highlight that they make Christian material key to the practice of interpretation. It is also possible to find treatments of religiously invested interpretation of sacred texts that do not deploy the resources of any single religious tradition as their lead categories, but that rely instead on terms designed to encompass and illuminate multiple religious traditions by stressing what they all have in common. ${ }^{3}$ For those who find either a theological or a religious account attractive, a key element of their appeal is often that theological/religious commitment seems to the interpreters to be comprehensive in its scope: it applies to

\footnotetext{
${ }^{1}$ Stephen E. Fowl, Engaging Scripture: A Model for Theological Interpretation (Oxford: Blackwell, 1998), p. 8.

${ }^{2}$ Darren Sarisky, Reading the Bible Theologically, Current Issues in Theology (Cambridge: Cambridge University Press, 2019), pp. 144-56.

${ }^{3}$ Paul J. Griffiths, Religious Reading: The Place of Reading in the Practice of Religion (Oxford: Oxford University Press, 1999); Wesley A. Kort, Take, Read: Scripture, Textuality, and Cultural Practice (University Park: Pennsylvania State University Press, 1996).
} 
absolutely everything that they do, and therefore it must apply to reading scriptural texts. ${ }^{4}$ So much for the debate in the background.

The query in the foreground for this essay is this: if the comprehensive scope of theological/religious commitment has entailments for how the Bible is interpreted, does it also have implications for how non-scriptural texts should be understood? The term nonscriptural here refers to texts that do not count as scripture for any religious tradition. ${ }^{5}$ Does a Christian's theological commitment have implications for how literary texts from outside the Bible should be read? If so, what are those implications? Is there, or should there be, any such thing as theological interpretation of texts that are non-scriptural in this sense? The question becomes more interesting on the stipulation that such literary texts differ at least in some real measure from the Bible itself without negating it entirely (I will thus use the term non-biblical in addition to non-scriptural in making reference to these works). There are, of course, texts such as John Milton's Paradise Lost, which is largely an imaginative commentary on a biblical episode. On the other end of the spectrum, there are works such as Philip Pullman's The Good Man Jesus and the Scoundrel Christ, which aims thoroughly to repudiate the biblical portrait of Jesus by constructing an alternative narrative. The literature with which this essay is mainly concerned lies somewhere between these two extremes, being neither an expansive gloss on the Bible nor an antithetical story. To the degree that there is not a difference in content between the Bible and the non-biblical literature I wish to examine, the query would begin to collapse back into the question of the meaning of theological/religious reading of the Bible. To the degree that there are no similarities between the Bible and non-biblical literature, it is hard to see how the non-biblical texts could

\footnotetext{
${ }^{4}$ On comprehensiveness as a mark of what it means to be genuinely religious, see Griffiths, Religious Reading, pp. 7-9.

5 For works in which Christian authors wrestle with scriptural texts from other religions, see the series of which this text is the inaugural volume: C. Cornille, Song Divine: Christian Commentaries on the Bhagavad Gītā, Christian Commentaries on Non-Christian Sacred Texts (Leuven: Peeters, 2006).
} 
point readers in the same direction as the Bible — an issue on which the essay will expand in what follows. Hence, when the terminology of literary texts is used in this essay, it refers to literary texts from outside the biblical canon that do not approach being identical in content with that same canon or the direct opposite of it, and that also do not count as scriptural texts for any other religious tradition.

Distinguishing this question from a few related issues will bring the main query into sharper focus. The issue here is not how explicitly Christian themes surface in very obvious ways in literary texts, as in authors from the western literary canon such as the metaphysical poet John Donne. Thinking about how Christian theological themes receive articulation in Donne's verse would mean exploring the content of what he says - an entirely worthwhile pursuit. Yet the purpose of this essay is to ask whether Christian commitment on the part of the reader of literary texts has implications for how that reader interprets literature. Likewise, the issue here is not about how knowledge of the biblical text can unlock the subtler biblical symbols and allusions that are prevalent throughout Western literature. As Northop Frye says in his Great Code with reference to the Bible and the West, 'A mythology rooted in a specific society transmits a heritage of shared allusion and verbal experience in time, and so mythology helps to create a cultural history'. ${ }^{6}$ This second topic is also an eminently worthy one to explore. But the question here is simply different. This essay deals with the work that Christian theological commitments do or could do hermeneutically in relation to nonscriptural literary texts. There should be such a thing as theological reading of non-biblical texts-if there were nontrivial work for such convictions to perform.

That there should indeed be such a thing as theological reading of non-biblical texts follows from understanding these documents as a collection of signs pointing toward the

\footnotetext{
${ }^{6}$ Northrop Frye, The Great Code: The Bible and Literature, ed. Alvin A. Lee, vol. 19 of Collected Works of Northrop Frye (Toronto: University of Toronto Press, 2006), p. 52.
} 
Christian God. Literary texts are not privileged signs: that role is reserved for the Bible. Yet literary texts can serve as signs nonetheless when they are read in light of biblical texts. They exercise this semiotic function when aspects of the truth of Christian doctrine are found within them. Sustaining this thesis, however, requires grappling with two objections. The first is that the proposed mode of interpreting literary texts foists a pre-determined meaning upon them; readers thereby fail to attend to the texts in their own integrity. This critique will receive attention immediately below in the section on the status questionis. The other obstacle to overcome is the charge that the way of reading being envisaged amounts to a form of natural theology of the sort that Karl Barth found deeply objectionable. Does this proposal deal with literary resources from the broader culture in such a way as to neglect christology and thus count as a version of natural theology? The final main section of the essay will return to both of these critical questions.

\section{State of the question}

This section can be brief because, as Alan Jacobs rightly says, few people today consider the reading of non-biblical texts to be a theologically significant activity. ${ }^{7}$ Accordingly, there is little current literature on the topic. That said, it is certainly worth noting that there is substantial historical precedent within other periods — not least in the early Christian centuries - for this sort of reading. The formative years for the Christian tradition witnessed some calls for believers entirely to eschew reading any non-biblical texts, on the grounds that there were only outright conflicts between Athens and Jerusalem, and thus nonbiblical texts could not be genuinely edifying. For the most part, however, strident, categorical refusals of engagement gave way to efforts to see points of resonance or even

\footnotetext{
7 Alan Jacobs, A Theology of Reading: The Hermeneutics of Love (Boulder: Westview, 2001), 111. A full exploration of why this is the case is beyond the scope of this essay. But Nicholas Wolterstorff rightly observes that religion is often thought to need explaining rather than as offering explanations, and this is surely part of why there is rather little literature on this issue. For his observation, see Art in Action: Toward a Christian Aesthetic (Grand Rapids: Eerdmans, 1980), pp. 86-8.
} 
significant correspondences between these two bodies of literature. ${ }^{8}$ Examples of this can be found in both Latin and Greek writing. ${ }^{9}$ For instance, in his Confessions, Augustine lamented the way he had read Virgil as a schoolboy, having such sympathy for Dido, while at the same time failing to see that his own estrangement from God was a far more substantial problem. Yet major portions of Confessions can be read as a Christian representation of the Latin epic: Augustine's text contains literary signals that it intends to rework Virgil's with a view toward demonstrating that the only true patria is being with God, rather than residing in any earthly city, and that the journey that is more consequential than any other is the one whereby the soul locates and comes to reside in its spiritual home. ${ }^{10}$ In the correspondence of Jerome, there is also some encouragement to engage discerningly with classical literary works. ${ }^{11}$ And, in addition, there is an address by Basil of Caesarea to school-age children on how to read Greek poetry and prose toward a Christian end. ${ }^{12}$ The present essay does not present a comprehensive reading of this literature, but the constructive position it develops makes reference to Basil's address, which is the most developed and explicit of the texts mentioned here in offering principles for this kind of reading. ${ }^{13}$

\footnotetext{
8 See the useful historical sketch of these two trajectories in Guy G. Stroumsa, 'Scripture and Paideia in Late Antiquity', in Homer and the Bible in the Eyes of Ancient Interpreters, ed. Maren Niehoff, Jerusalem Studies in Religion and Culture (Leiden: Brill, 2012), pp. 30-5.

9 Carol Harrison helpfully notes that Eastern writers are more sanguine than their Western counterparts in bridging between the classical culture of antiquity and something specifically and distinctively Christian, though she confesses that not all the reasons for this are utterly clear: Augustine: Christian Truth and Fractured Humanity, Christian Theology in Context (Oxford: OUP, 2000), pp. 53-4.

10 See, for instance, Camille Bennett, 'The Conversion of Vergil: The Aeneid in Augustine's Confessions', Revue des Études Augustiniennes 34 (1988), pp. 47-69.

11 There is a translation of the primary text, Jerome's letter 70, in Philip Schaff (ed.), Jerome: Letters and Select Works, vol. 6 of The Nicene and Post-Nicene Fathers, Second Series (Grand Rapids: William B. Eerdmans, 1954), pp. 149-51. For useful analysis of the side of Jerome that, at least prima facie, seems to want to reject his classical cultural inheritance on Christian grounds, see David L. Jeffrey, People of the Book: Christian Identity and Literary Culture (Grand Rapids: Eerdmans, 1996), pp. 75-6.

12 Saint Basil, The Letters, vol. IV, Loeb Classical Library (Cambridge: Harvard University Press, 1970), pp. $378-435$.

13 It is also worth noting that in the patristic period and later, there came to be many rewritings of 'pagan' literary works. For a study of the Acts of Andrew, a retelling of Homer's Odyssey so as to bring the story within a Christian register, see Dennis R. MacDonald, Christianizing Homer: The Odyssey, Plato, and the Acts of Andrew (Oxford: Oxford University Press, 1994).
} 
Though there are few recent treatments of our topic, Alan Jacobs's A Theology of Reading is the most important current constructive work to deal with it. ${ }^{14}$ Jacobs draws from Augustine a strong argument that theological allegiance definitely should influence how readers understand all texts, both biblical and non-biblical ones. ${ }^{15}$ Augustine sees the dominical command to love God and neighbour as utterly comprehensive in scope, including every pursuit to which one might put one's hand, and thus as not excluding textual interpretation. As Jacobs sees it, the obligation to love one's neighbour implies certain things about how to treat one's human neighbours, but by extension it also has entailments for how we interact with texts, the expression in writing of another person's thoughts and feelings. Jesus' command requires that readers attend closely to the actual voice of texts they are engaging. They must listen to them in an effort to discern what they have to offer: not in a spirit of suspicion, which assumes the sufficiency of the self, but with a view toward attending to the other. It is on precisely this basis that Jacobs opposes what he refers to as allegory, meaning the attempt to interpret texts that evidently are not fully Christian as if they were somehow offering up a message that is Christian in content. ${ }^{16}$ This is incompatible, for Jacobs, with his hermeneutic of love because the allegorical method risks the erasure of differences - including the difference between ourselves and the others we are supposed to love. ${ }^{17}$ Jacobs's argument that theological convictions should not be set aside in reading literary texts is compelling. And the question he raises about the patristic precedent for how to do this is serious enough that it deserves a full response in what follows.

\section{Reading non-privileged signs}

\footnotetext{
14 There is also a historically oriented treatment of our issue in Jeffrey, People of the Book, pp. 71-96. In addition, there are relevent reflections in Susan V. Gallagher and Roger Lundin, Literature Through the Eyes of Faith (New York: HarperOne, 2014), though the book is essentially a textbook for students.

15 Jacobs, A Theology of Reading, pp. 10-11.

16 I will return below to the question of whether this is the best terminology.

17 Jacobs, A Theology of Reading, pp. 12-14. There is a very similar question in Jeffrey, People of the Book, p. 72 , on which Jacobs is building.
} 
This brings the discussion to the point of developing a constructive position on theological reading of non-scriptural texts. The view proposed below presupposes a construal of the biblical text that is commonplace within the Christian tradition. That is, it takes for granted that the Bible is a set of signs that direct the attention of the reader toward the triune God. Or, to gloss the matter in closely related terms, the texts are not fundamentally about themselves; they signify or indicate the being and act of the Christian God. In looking back and reflecting on a comprehensive history of biblical interpretation, David Tracy rightly comments, 'For Christianity is not a religion of the book, yet the book plays a central role in Christian self-understanding. Christianity, in more explicitly hermeneutical terms, is a religion of a revelatory event', and certain texts signify or point readers toward this event. ${ }^{18}$ The sequence of words that constitute the Old and New Testaments, the two-testament canon of Scripture, are signifiers to the event by which God makes himself present in the person of Jesus Christ. It is Jesus Christ, the Son of the Father, present and active in the power of the Spirit, who is signified or testified to by the written words of the Bible. ${ }^{19}$

That the text is essentially concerned with what it signifies, as opposed to the words properly representing the final terminus of readerly effort, means that there is something outside the text that the reader accesses by means of it; yet this does not mean that interpretation is simply a matter of establishing the referent of biblical signifiers. To claim that the Bible is a set of signs is not the same as asserting that its meaning is reducible to its reference. The Bible brings its readers into relation with what it signifies; however, it relates

\footnotetext{
18 Robert M. Grant and David Tracy, A Short History of the Interpretation of the Bible, 2nd ed. (Minneapolis: Fortress, 1984), p. 177.

19 Since this is a view of the Bible that not all readers have, one could potentially say that it is the convictions of the reader that impel interpretation in a specifically theological direction. I am framing the matter as a view of the text in order to stress that it is the reader's convictions about the text that are at issue. Seeing the biblical text as a set of signs pointing to God is to make a claim about what the text really is.
} 
readers in various ways to this subject matter, for instance, by saying things about it, by expressing wishes with respect to it, by communicating mandates to the reader on behalf of the one whom the text signifies, and so on.

Since the religious vision arising from the Bible is comprehensive in scope, such theological convictions form a framework within which all of the reader's other convictions find their proper place. A genuine commitment to comprehensiveness does not mean merely that what the Bible has to say about God relates in some way to every other subject, so that the two discrete domains should be correlated with one another in various ways, whereby some sort of conversation between the text and the full range of human knowledge is always possible in principle, even if its form cannot be predicted in advance. ${ }^{20}$ To set biblical conceptions alongside the claims of various disciplines is different from treating the Bible as an encompassing framework within which to engage all issues. Erich Auerbach is correct in observing that the Bible presents a view of the world that calls for readers to situate themselves and their beliefs inside its purview. Scripture, he says presents universal history: it begins with the beginning of time, with the creation of the world, and will end with the Last Days, the fulfilling of the Covenant, with which the world will come to an end. Everything else that happens in the world can only be conceived as an element in this sequence; into it everything that is known about the world ... must be fitted as an ingredient of the divine plan; and as this too became possible only by interpreting the new material as it poured in, the need for interpretation reaches out beyond the original Jewish-Isrealitish realm of history-for example to Assyrian, Babylonian, Persian, and Roman history; interpretation in a determined direction becomes a general method of comprehending reality; the new

\footnotetext{
20 Here I differ from David Tracy, The Analogical Imagination: Christian Theology and the Culture of Pluralism (New York: Crossroad, 1981). On his view, a conversation between text and situation can take one of three basic forms: a confrontation of the situation by the message of the text, an agreement between the two as there is an identity in meaning or content, or a negotiation of both similarities and differences.
} 
and strange world which now comes into view and which, in the form in which it presents itself, proves to be wholly unutilizable within the Jewish religious frame, must be so interpreted that it can find a place there. ${ }^{21}$

The present essay concentrates on just the sort of material that Auerbach says 'poured in' from beyond the reaches of a fundamentally Jewish frame of reference. This includes texts such as those from Homer, who operates so differently than the Bible, not seeking to have readers find themselves in the world of his poetry, but asking us to 'forget our own reality for a few hours'. ${ }^{22}$ What does it mean to read these works in light of the Bible?

The necessity of absorption, rather than correlation, leads to a further refinement of the previously stated view of the Bible. The Bible is not only a set of signs pointing the reader to God; it is a privileged collection of signs, which is to say that whatever other genuine signs there are must be read in relation to it. Whatever else signifies what the biblical signs do must speak in harmony with the prophets and apostles, being understood with reference to the framework they establish with their words. For example, the created order can serve as a non-privileged sign. In Basil's homilies on the text of Genesis, various aspects of the natural order point beyond themselves to their transcendent ground in the God who created the world. Basil does not limit himself to repeating only exactly what the text says about how the world was created by God. He goes beyond this and seeks to do

\footnotetext{
${ }^{21}$ Erich Auerbach, Mimesis: The Representation of Reality in Western Literature (Princeton: Princeton University Press, 1968), p. 16.

${ }^{22}$ Auerbach, Mimesis, 15. It will be evident that I am in sympathy here with Hans Frei's fourth type of theology, in which theologians draw other discourses within a specifically Christian framework: Types of Christian Theology (New Haven: Yale University Press, 1992), pp. 38-46. Although Frei also explores how his first three types have implications for biblical interpretation (Types of Christian Theology, pp. 56-69), I am dealing with the consequences of seeing theology according to the fourth type for the interpretation of nonbiblical material. For how interpretation of art and literary texts works for type two, see Tracy, The Analogical Imagination, pp. 99-135; if one has this strong of a commitment to general hermeneutics, then the reading of both biblical and non-biblical texts becomes a process of mutually critical conversation between two sources, in which neither has a privileged position in the dialogue. For a classical example of type three, see Friedrich Schleiermacher, On Religion: Speeches to Its Cultured Despisers, 2nd ed., Cambridge Texts in the History of Philosophy (Cambridge: Cambridge University Press, 1996), pp. 68-71, who also discusses art generally while making some application to literary art.
} 
something more ambitious by 'shaping patterns of attention' to the created order, ${ }^{23}$ ones that recognize the fundamental difference between God and the world, while at the same time displaying alertness to how its reality attests to the one who formed it and continues to preserve its order in the present. Taking as his point of departure that God speaks to the world and produces living creatures 'of every kind' (Gen. 1:24, NRSV), Basil observes that the reproduction of natural kinds within the world is a sign of the care of God and his role in providing order to the process of reproduction. ${ }^{24}$ The present point is simply to establish the meaning of the category of non-privileged signs, and to offer a modest amount of illustration, not to delimit in any definitive way what does or does not count as a non-privileged sign.

Later in this section, it will prove possible to ask directly whether non-biblical literary works qualify as non-privileged signs. Clearly, though, they do at least have a semiotic function: they say something, and they can say something about matters of transcendence. How so? It is too much to say that every piece of literary art must necessarily express the religion of the artist. This is not only because some art expresses secular concerns, though that is obviously true. It is also because, even if 'religion' refers to a person's life becoming fixed on something that functions as an ultimate unifying concern, it is not clear that all lives have such a single unifying centre. ${ }^{25}$ Some lives are marked by a range of concerns that shift from time to time, remain finally fragmented, and are not held together by a single focus that sets everything in perspective and continues to function in that way for an extended period of time. ${ }^{26}$ Thus, not every literary work expresses religion in this straightforward way. Yet, for every literary text, there is always what Nicholas Wolterstorff calls a 'world behind the

\footnotetext{
${ }^{23}$ Lewis Ayres, Nicaea and Its Legacy: An Approach to Fourth-Century Trinitarian Theology (Oxford: Oxford University Press, 2004), p. 315; emphasis added.

${ }^{24}$ Ibid., p. 316.

${ }^{25}$ Wolterstorff, Art in Action, pp. 86-8. He is articulating a theology of art more generally. I apply his view to literary art specifically.

${ }^{26}$ Ibid., p. 86.
} 
work', ${ }^{27}$ of which the work is itself an expression. The world behind the literary work refers to 'that complex of the artist's beliefs and goals, convictions and concerns, which play a role in accounting for the existence and character of the work' ${ }^{28}$ These can relate to rather minor matters, or they can concern issues of ultimate significance, in which case the piece of literature expresses a full-blown worldview. ${ }^{29}$ It is often the case, therefore, that the religion of the author, or the author's particular version of secularism, has a central role in the world the text portrays. ${ }^{30}$ In the Odyssey, for instance, Homer is not attempting to claim that a real human being named Odysseus at some point in the past actually did all the things that the epic relates. The poem, however, does express the beliefs and convictions of the poet, central to which is the vision of virtue that Odysseus embodies in his life. The text has a religious dimension, in a loose sense, insofar as it suggests where a human being should stand in relation to different versions of transcendence. The work intimates that Odysseus belongs with his human wife, rather than with a divine consort, and that his particular virtues, chief among which is craftiness, are a form of specifically human excellence, which would have almost no meaning for a divine being who does not also have the inherent limitations of a human person. ${ }^{31}$ Odysseus ought to be wily and determined, but the life of an immortal is just not his, and he should accept this restriction.

If such texts make claims, as a function of the world behind the work, and even make claims about matters more ultimate than merely mundane affairs, can they be taken to speak

\footnotetext{
27 Ibid., pp. 88-90. The 'world behind the work', as Wolterstorff uses this language, is not identical in meaning to, though there is overlap with, similar terminology associated with Paul Ricoeur, that of the 'world behind the text'. 'The world behind the text' refers to the text's circumstances of origin and the author's outlook. Another aspect of Ricoeur's outlook, 'the world in front of the text', signals, by contrast, the 'direction of thought opened up by the text', which the reader may explore as a possibility for her own life. For this quotation and the contrast between in front and behind, see Paul Ricoeur, Interpretation Theory: Discourse and the Surplus of Meaning (Fort Worth: Texas Christian University Press, 1976), p. 92.

28 Wolterstorff, Art in Action, p. 89.

29 Ibid.

30 Ibid.

31 Martha Nussbaum, 'Transcending Humanity', in Love's Knowledge: Essays on Philosophy and Literature (Oxford: Oxford University Press, 1992), pp. 365-90.
} 
of issues that are specifically Christian? Is it legitimate to see them as speaking of the triune God and of faithful human response to him? Can the category of non-privileged signs properly apply to them? Of course, there are two logically possible answers: no and yes. Both of these responses have precedent in the early centuries of the Christian tradition, as was mentioned in the section above on the state of the question. It is possible to reject the possibility that non-biblical literary texts have something to say about the Christian God. The basis for taking this line is simply the prima facie differences in material content between the canonical texts and literary texts that are different from the Bible. To be sure, if the two bodies of writing are not identical in what they say, then there is at least a danger of a onesided assimilation of Christian scripture to alien texts or vice versa. But this risk is more a result of hasty or sloppy reading than a problem that will certainly and of necessity occur by the nature of the case. If there are differences between these texts, it is necessary for a careful reader to register them. Thus, the other option, first recognising genuine similarities between non-Christian material and normatively Christian texts, and then recontextualising these echoes of the Bible in light of the Bible, is a more compelling approach. ${ }^{32}$ Basil stresses that Christians should utilise everything that can aid the Christian life so as to maximise that contribution: 'Our hopes lead us forward to a more distant time, and everything we do is by

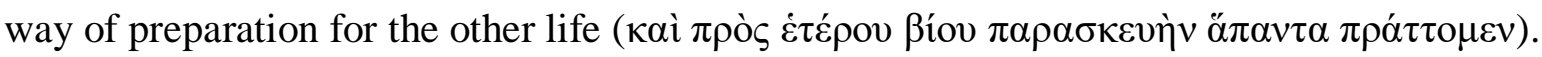
Whatever, therefore, contributes to that life, we say must be loved and pursued with all our strength' ${ }^{33}$

\footnotetext{
32 Averil Cameron is certainly right that there were strategic or tactical questions at issue in how early Christians decided to read classical texts. For some reference to Basil as well as others, see her Christianity and the Rhetoric of Empire: The Development of Christian Discourse (Berkeley: University of California Press, 1991), pp. 138-41.

33 Basil, The Letters, pp. 381-3. In connection with literary works, this does not so much mean that the category of general revelation includes imaginary and therefore non-existent things, as it does that the products of human culture may effectively function as a type of sign.
} 
Reading a non-biblical text in light of the Bible, and thus as a collection of nonprivileged signs, means following three steps. First, it requires working through the nonbiblical text in order to differentiate between what in it is similar to the content of the Bible and what is substantially different. Second, it requires rejecting the material that is genuinely opposed to what readers glean from the Bible. On the one hand, Basil describes the presentation of Christian truths by non-scriptural literary material as a way of seeing these

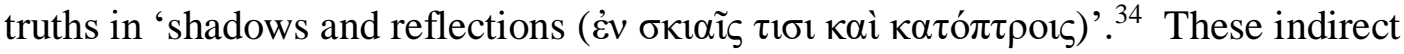
presentations of truth have value even if they are not the most definitive way in which a reader may learn them. But, on the other hand, content that does not fall into this category cannot be appropriated by the Christian reader. It must be repudiated. Third, reading these texts theologically requires adapting the appropriated material so that it fits more fully into a Christian framework. Basil comments, 'At the very outset, therefore, we should examine each of the branches of knowledge and adapt it to our end, according to the Doric proverb, "bringing the stone to the line". ${ }^{35}$ Some contemporary scholars of Basil's text find fault with him for not reading Greek classic texts 'straight', or for putting his own misleading spin on how literary characters model virtues that seem worthy of Christian imitation. ${ }^{36}$ It is, though, the very essence of his mode of interpretation to see how non-biblical material can, in its own way, represent biblical teaching, even while the two bodies of literature are clearly and

\footnotetext{
34 Ibid., p. 383.

35 Ibid., p. 393.

36 Ernest L. Fortin, 'Hellenism and Christianity in Basil the Great's Address Ad Adulescentes', in Neoplatonism and Early Christian Thought (London: Variorum Publications, 1981), pp. 189-203; Philip Rousseau, Basil of Caesarea (Berkeley: University of California Press, 1994), pp. 53, 56, 59. Much more helpful is the treatment in Kathy Eden, Hermeneutics and the Rhetorical Tradition: Chapters in the Ancient Legacy \& Its Humanist Reception (New Haven: Yale University Press, 1997), pp. 42-53, who uses concepts from Basil's rhetorical/interpretive training to analyse his reading, not as attending in a strict sense 'to the letter' of the classical works, but rather as focusing more on 'the spirit' of the text, accommodating it to the needs of the audience. (Interestingly, Jacobs speaks approvingly of this reading strategy, and cites Eden in doing so, though he does not explain how this differs from the allegorical mode of which Jacobs so clearly disapproves: $A$ Theology of Reading, pp. 138-9, 141-4.) Though his topic is slightly different, there is also value in Gérard Genette, Palimpsestes:la littérature au second degré (Paris: Éditions du Seuil, 1992), pp. 418-9. He is insightful on how reconfigurations of texts work to subvert certain values while uplifting and recommending others.
} 
obviously not identical —as he is well aware. This is not a matter of taking arbitrary liberties with texts, but of situating content deemed useful within a biblical framework, which is taken to be completely comprehensive in its scope. ${ }^{37}$ In sum, then, the three steps are: sorting, rejecting, and appropriating (together with recontextualisation).

These steps are logically separable from each other, even if the phases are not chronologically separable or easy to distinguish in practice; but for present purposes, it is crucial to note how the first step contrasts with the subsequent two. On the one hand, the initial moment is about coming to terms with the literary text and comparing it to the standard of a Christian theological framework, thereby deciding which aspects of the non-biblical text chime in with the overall thrust of the Bible. This requires reading the non-biblical texts as a work with its own integrity and purpose, for without doing that it would not be possible to make valid comparisons. On the other hand, the second two moments pertain to the dialectic of rejection and appropriation, which builds on the comparative work. The second and third steps reject what is incompatible with Christian theology and situate only what can actually be incorporated within its scope. The contrast between the second two steps and the first regards making a judgment on the basis of an established theological framework and integrating within it just what has the potential to come inside it. Each of the three steps is important, but the next section will consider stages two and three together in dealing with the problem of allegorical reading identified by Jacobs, as well as making explicit how this grouping puts a specifically modern twist on the procedure that Basil recommends.

\footnotetext{
37 Michael Fishbane sees very deeply into the operation of an analogous phenomenon within the Hebrew Bible, and is thus not tempted to offer ill-founded critique. He comments, "For in so far as the "later correspondents" occur in history and time, they will never be precisely identical with their prototype, but inevitably stand in a hermeneutical relationship with them. ... In the Hebrew Bible such nexuses are the product of a specific mode of theological-historical speculation - one which seeks to adapt, interpret, and otherwise illuminate a present experience (or hope, or expectation) by means of an older datum'. See his Biblical Interpretation in Ancient Israel (Oxford: Clarendon Press, 1985), pp. 351-2.
} 
Before answering objections, suppose we briefly consider how this proposal might work, starting with a negative example and moving on to a positive one. The idea is not at all to say with Joseph Campbell that a diverse range of literary characters — say Prometheus, Aeneas, and even Jesus - all embody the constituent elements of a universal interpretive category such as 'hero', according to which the hero is one who separates himself from everyday life, undergoes an initiation into a realm that is in some sense supernatural, and then returns to the world in order to induct others into the mysterious domain from which he has just returned. ${ }^{38}$ This interpretive category of hero is generic in content, for it does not reflect the particularities of the stories of Prometheus, Aeneas, or Jesus, even as it encompasses them all within its scope. This is not what theological reading of non-biblical texts is about because, at a very obvious level, the main narratives about Jesus are the biblical ones, and also because that which is signified here is a universal trope or a set of characteristics that run through a group of examples, not something specifically theological. Read in this way, these texts all point their readers to 'the hero'.

Theological reading of literary works involves, instead, seeing the Christian God as that to which the textual signifiers point. For instance, in the novel Lord of the Flies, the character Simon bears a number of rather striking resemblances to Jesus Christ: he looks vaguely like Jesus, he sometimes seeks out moments of solitude, he has a confrontation with a symbol of evil in his conversation with the head of a slaughtered pig that has been impaled on a stick, and he is murdered when he attempts to bring a true message to the members of his community. ${ }^{39}$ Of course differences between Simon and Jesus remain, but Simon cannot but bring Jesus to mind. A reader would not ultimately need a hermeneutical framework that is theological in any significant respect to note these intertextual connections. They are there

\footnotetext{
38 Joseph Campbell, The Hero with a Thousand Faces, 2nd ed., Bollingen Series (Princeton: Princeton University Press, 1968), pp. 30-40.

39 William Golding, Lord of the Flies, Special ed. (London: Faber \& Faber, 2014).
} 
for any reader to notice. What theological reading of literary works does is to construe the literary signs as non-privileged pointers to God, thereby ensuring that what is signified is materially theological, and holding at bay a generic hermeneutic that would otherwise preclude efforts to discern content of theological value across a variety of literary texts. ${ }^{40}$ This is not to say that a generic hermeneutic should be categorically excluded, but that a theological reading should also be afforded scope to operate.

\section{Response to objections}

It remains now to respond to the two objections. First, is Jacobs rightly worried that what is being proposed here, which takes its cue from Basil and others, is allegorical reading in the sense that it finds a meaning in texts other than what careful, attentive, respectful listening would actually discover? If what is wrong with Campbell's way of interpreting spiritual heroes is that his way of understanding Jesus mutes the distinctives with which the New Testament presents him, then is it not the case that what is being recommended above is just the reverse of this, a way of muffling the particular voice that one ought to be able to hear by attending to non-scriptural literary texts, which are forced by this way of reading them to articulate a specifically Christian message?

The model developed above does not involve making texts say what they do not mean (the focus of Jacobs' worry). The distinction between different phases of reading should make this clear. As the previous section spelled out, the first phase of interpretation calls for readers to come to terms with the literary work and to make a judgment about which of its elements are similar to, and which are different from, the overall arc of the biblical narrative. This is a matter of understanding the nature of the world behind the work and assessing it in

\footnotetext{
40 I leave open precisely how broadly this model can be applied. Can absolutely all non-scriptural literary works function as non-privileged signs to the Christian God? My suggestion here is just that it can work with many texts that are non-canonical and different in their content from those that are. In practice, this approach is likely to be more fruitful in connection with some texts than with others.
} 
relation to the Bible. For the non-scriptural text, what are the author's beliefs, convictions, and concerns as these receive expression in the text? Seeing the world behind the work as accurately as possible necessitates reading passages of the work in their own context and in their own integrity. When readers do this, they cannot help but see where non-biblical texts stand in marked contrast to the constituent texts of the biblical canon. Barth's exclamation to this effect is entirely understandable: 'We may quietly listen to others. We may hear what is said by the whole history of religion, poetry, mythology, and philosophy. We shall certainly meet there with many things which might be claimed as elements of the Word spoken by Jesus Christ. But what a mass of rudiments and fragments which in their isolation and absoluteness say something very different from this Word' ! ${ }^{41}$

The next part of the reading process—rejecting and appropriating—which I group together for the sake of convenience, is not about understanding what the world behind the work is. It is about how to understand the world of the work from a Christian vantage point. In other words, the question here is not what the texts say; it is what to make of what they say. At this point, understanding them in a Christian way concentrates on the place their subject matter could have within a Christian framework. In this way, the idea is not that nonbiblical texts are assimilated, but only after the initial phase of the process. On the model proposed here, in which a distinction is made between assimilation and appropriation, literary texts are never assimilated, because the later phases of interpretation, whether in the mode of rejection or appropriation, make no claim about textual meaning. There is no possibility for distortion of meaning because the focus of interpretive energy has shifted decisively in stages two and three. The work of these final phases is thus not different in kind from Freud's reading of religion, which he compares to the way an adult understands the figurative

${ }^{41}$ Karl Barth, Church Dogmatics IV.3/1, study edn. (London: T. \& T. Clark, 2010), p. 108. 
language of a stork delivering a newborn baby to its parents. ${ }^{42}$ Adults know how children really are produced and understand such expressions accordingly: they make sense of the reference to the stork by situating the claim within an outlook that reflects the basics of human biology. So also the later stages of interpretation in the model being articulated here concern themselves with how a reader whose viewpoint has definite intellectual structure (that of Christian theology) might process textual claims from her point of view.

Distinguishing stages in this way may raise questions about whether the first, 'sorting', stage of interpretation receives an exemption from the requirement of comprehensiveness. Theological beliefs and convictions may have a modest role in determining what a literary texts says: perhaps, à la Jacobs, they may motivate this phase of the interpretive process by prompting a reader to listen to and thus in some sense love one's neighbour. But theological commitment does not do here what it does in the later phases, where it governs the process of appropriation. It can operate differently at different stages, while still being genuinely operative from beginning to end. It is still truly operative when due effort is made to see what the non-privileged signs are before exploring how they ultimately signify what they do. Thus no aspect of the interpretive process is an exception to the rule of comprehensiveness.

This understanding of appropriation provides a basis for responding to Jacobs' worry about the dangers of what he calls allegorical reading. In fact, what is being proposed here as echoing Basil's approach is not allegory at all; it corresponds rather to what Frances Young calls 'mimetic reading'. ${ }^{43}$ Specifically, it is a form of mimesis in that it deals with figures in Greek literature as representing Christians and the virtues that they ought to embody in their lives. More specifically, much of it is an 'ikonic' version of mimesis (as opposed to symbolic

${ }^{42}$ Cited in Campbell, The Hero with a Thousand Faces, p. xii.

${ }_{43}$ Frances M. Young, Biblical Exegesis and the Formation of Christian Culture (Cambridge: CUP, 1997), pp. 209-13. 
mimesis, which Basil does use in other contexts), which attends to larger-scale and more substantial resemblances between the textual signifier in Greek literature and the corresponding quality in Christian thought. ${ }^{44}$ For instance, Basil mentions the example of Socrates not reacting with violence to a man who assaulted him: this approximates or resembles Christian teaching about forgiveness. ${ }^{45}$ As Young rightly notes, any reading strategy that seeks out the mimetic potential in a text is bound to underscore whatever similarities exist and to downplay or elide differences. ${ }^{46}$ What is being proposed here is a retrieval of ikonic mimesis that takes its cue from Basil, but that is not identical with his approach. The Cappadocian is certainly not unaware of how the Greek literature differs from the Christian Bible. There is, though, a firmer in-principle distinction here between interpretive stages, wherein the first ascertains what a text says and assesses it from a Christian point of view ('sorting'), while the subsequent stages appropriate what they can and reject what they must ('making one's own'). ${ }^{47}$

With this clarification of 'allegory' in place, it is possible to deal more briefly with the second objection raised by this approach: whether the view of theological reading of nonscriptural texts being proposed qualifies as natural theology. For Barth, natural theology refers to any attempt to know God apart from the divine self-disclosure that Jesus Christ alone provides. ${ }^{48}$ There is actually no other path to knowledge of God than this one, and so attempts to travel some other supposed route inevitably devolve into idolatry. If the position detailed above seems to correspond to this description of natural theology, it is because the act of engaging with non-scriptural literary texts is not obviously and directly christological.

\footnotetext{
44 There is certainly a strongly paranetic element as well. See Ibid., pp. 209-10.

45 Basil, The Letters, p. 405.

46 Young, Biblical Exegesis and the Formation of Christian Culture, p. 191.

${ }^{47}$ Again, there is an analytical distinction to be made between phases two and three, but what is key here is the difference between two and three taken together, as compared with one. One is the only stage that deals with the sense of the text as an integral whole.

48 Barth, Church Dogmatics IV.3/1, pp. 117-8.
} 
The whole nature of the problem is to reflect upon what is happening when readers engage with texts other than the privileged signs to be found in the Bible itself, the text that explicitly points its readers to Jesus Christ. Yet if it is true that the literary works in question are not obviously and directly christological, reading them theologically nevertheless means interpreting them in light of the christology that the Bible itself generates. Reading nonbiblical texts theologically thus operates on the basis of what might be called a reflected christology. Non-biblical literary texts thus shine more like the moon than the sun, but they nevertheless do actually shine. ${ }^{49}$ There is christology in place here, therefore this is not an example of natural theology.

\section{Conclusion}

To summarise the argument in conditional form: if one assumes that theology should function as a broad framework that structures one's beliefs and practices, though it does not determine all the details of those beliefs and practices, then non-biblical literary materials become a set of non-privileged signs to the Christian God, and such texts can be read using a reading strategy in continuity with patristic practices of appropriating non-Christian texts, without readers thereby projecting Christian views onto these texts, and without their doing an end run around christology in considering how the texts refer to God. Of course, one might ask why readers should bother engaging with other literary works, if they can find whatever theological content may be available in these texts in its definitive form in Scripture itself. The answer is that doing so can serve as a way to take every thought captive to Christ (2 Cor. 10:5) and allow him to be seen from new angles. Engaging with these texts as nonprivileged signs, rather than eschewing them altogether, opens a whole literary universe for properly theological exploration. This is less about learning entirely new and totally

\footnotetext{
49 I do not mean to suggest here that the Bible is the origin of its own light, as the sun is. What is important about Scripture is the way in which it functions as a set of signs pointing to its subject matter. To say more than this is to over-read my analogy.
} 
unprecedented theological content than it is about seeing what may be familiar from a new perspective, and seeing the semiotic potential of the broad range of texts as they direct readers to ponder a mystery whose depth can never be fully plumbed. 